\title{
Infectious Disease Risk Associated with Contaminated Propofol Anesthesia, 1989-2014
}

Andrés Zorrilla-Vaca, Jimmy J. Arevalo, Kevin Escandón-Vargas, Daniel Soltanifar, Marek A. Mirski

\section{$\underset{\text { MDUCATION }}{\text { Medse ACTIVITY }}$}

Medscape, LLC is pleased to provide online continuing medical education (CME) for this journal article, allowing clinicians the opportunity to earn CME credit.

This activity has been planned and implemented in accordance with the Essential Areas and policies of the Accreditation Council for Continuing Medical Education through the joint providership of Medscape, LLC and Emerging Infectious Diseases. Medscape, LLC is accredited by the ACCME to provide continuing medical education for physicians.

Medscape, LLC designates this Journal-based CME activity for a maximum of 1.0 AMA PRA Category 1 Credit(s) ${ }^{T M}$. Physicians should claim only the credit commensurate with the extent of their participation in the activity.

All other clinicians completing this activity will be issued a certificate of participation. To participate in this journal CME activity: (1) review the learning objectives and author disclosures; (2) study the education content; (3) take the post-test with a $75 \%$ minimum passing score and complete the evaluation at http://www.medscape.org/journal/eid; (4) view/print certificate.

Release date: May 11, 2016; Expiration date: May 11, 2017

\section{Learning Objectives}

Upon completion of this activity, participants will be able to:

- Assess the epidemiology of propofol-related infection.

- Identify the procedure associated with the highest number of propofol-related infections.

- Assess different sources of propofol-related infection.

- Evaluate other contributing factors in propofol-related infections.

CME Editor

Jean Michaels Jones, Technical Writer/Editor, Emerging Infectious Diseases. Disclosure: Jean Michaels Jones has disclosed no relevant financial relationships.

\section{CME Author}

Charles P. Vega, MD, Clinical Professor of Family Medicine, University of California, Irvine. Disclosure: Charles P. Vega, MD, has disclosed the following financial relationships: served as an advisor or consultant for Allergan, Inc.; McNeil Consumer Healthcare; served as a speaker or a member of a speakers bureau for Shire Pharmaceuticals.

\section{Authors}

Disclosurea: Andrés Zorrilla-Vaca; Jimmy J. Arevalo, MD, MSc; Kevin Escandón-Vargas, MD; Daniel

Soltanifar, MBBS, FRCA; and Marek A. Mirski, MD, PhD, have disclosed no relevant financial relationships.

Author affiliations: Universidad del Valle School of Medicine, Cali, Colombia (A. Zorrilla-Vaca, K. Escandón-Vargas); Fundación Universitaria de Ciencias de la Salud, Bogota, Colombia (J.J. Arevalo); Royal Free Hospital, London, United Kingdom (D. Soltanifar), Johns Hopkins University School of Medicine, Baltimore, Maryland, USA (M.A. Mirski)

DOI: http://dx.doi.org/10.3201/eid2206.150376
Administration of propofol, the most frequently used intravenous anesthetic worldwide, has been associated with several iatrogenic infections despite its relative safety. Little is known regarding the global epidemiology of propofol-related outbreaks and the effectiveness of existing preventive strategies. In this overview of the evidence of propofol as a source of

${ }^{1}$ Part of this work was presented at the XXXI Colombian Congress of Anesthesiology and Critical Care, Cali, Colombia, July 2015. 
infection and appraisal of preventive strategies, we identified 58 studies through a literature search in PubMed, Embase, and Lilacs for propofol-related infections during 1989-2014. Twenty propofol-related outbreaks have been reported, affecting 144 patients and resulting in 10 deaths. Related factors included reuse of syringes for multiple patients and prolonged exposure to the environment when vials were left open. The addition of antimicrobial drugs to the emulsion has been instituted in some countries, but outbreaks have still occurred. There remains a lack of comprehensive information on the effectiveness of measures to prevent future outbreaks.

$\mathrm{G}$ lobally, propofol is the most frequently used intravenous (IV) anesthetic for the induction and maintenance of general anesthesia (1). The chemical in propofol, 2,6-diisopropylphenol, is insoluble in aqueous solutions, so the solution is formulated as a nonpyrogenic emulsion containing soybean oil, purified egg phosphatide, and glycerol. This anesthetic has several favorable characteristics as a hypnotic agent, including rapid onset and elimination times, predictability and ease of titration, and a strong overall safety profile (1). Despite these benefits, propofol has been associated with the occurrence of healthcare-related infections $(2-4)$. The potential to cause infections has been attributed to the lipophilic nature of propofol formulations, a medium that strongly supports extrinsic bacterial growth at room temperature (5).

In 1989, the US Food and Drug Administration (FDA) approved propofol as an induction agent for general anesthesia. Since then, numerous reports of propofol-related infections have generated strong concern among public health officials (G), leading to the institution of strict aseptic handling protocols and, in some countries, the additional requirement of instilling antimicrobial additives to propofol formulations. In many countries, however, no such standards have been adopted, largely because of the additional costs involved and the argument that insufficient evidence exists for the effectiveness of such antimicrobial additives. In the United States, the American Society of Anesthesiologists and the Centers for Disease Control and Prevention have jointly recommended strict adherence to aseptic handling protocols of propofol (7).

There continues to be a lack of awareness of the occurrence of infections related to propofol use among healthcare providers (6). To our knowledge, no previous review has evaluated the characteristics of propofol-related outbreaks and the evidence supporting the use of existing preventive strategies. The aim of this article is to present an overview of the evidence of propofol as a source of healthcare-related infections.

\section{Selection Criteria for Studies}

We reviewed studies that reported on the occurrence of propofol-related infections in human subjects: single case reports, case series, retrospective chart reviews, crosssectional studies, prospective follow-up studies, and registries published in the form of short communications or original contributions. We also reviewed laboratory studies reporting on propofol as a microbiological reservoir and studies evaluating the effectiveness of bacterial growth retardants in propofol formulations. Studies reporting on propofol-related infections in animals were excluded, as were reports found in newspaper articles and government Internet sites. The latter sources, because they are not peer-reviewed articles, provide insufficient evidence for the association between propofol and infectious events.

\section{Search Methods for Identification of Studies}

We identified appropriate articles by searching PubMed, Embase, and Lilacs for reports published during January 1,1989-September 30,2014. The search was limited to articles published in or after 1989, which is the year propofol was introduced to clinical practice. The electronic search strategy for PubMed was "(propofol OR Diprivan) AND (infection OR outbreak OR contamination)." The search strategy was translated in accordance to the other database Boolean operators and was not limited by language. For this study, outbreak was defined as $\geq 2$ cases.

\section{Study Selection}

The titles and abstracts retrieved during the literature search were screened by 2 co-authors (A.Z.V., K.E.V.) independently for inclusion criteria. The full text of the selected studies was retrieved and related reference lists screened to identify additional publications. Disagreements on the selection of studies were solved by a third co-author (D.S.).

\section{Data Extraction and Management}

We stratified articles into 4 categories. 1) Features of propofol-related outbreaks worldwide (e.g., year, geographic localization, type of procedure, route of propofol contamination, type of microorganism isolated, number of cases, and number of deaths) were compiled for each outbreak during 1989-2014. Outbreak reports published more than once were occasionally encountered; only the most representative study was included to prevent data duplication. In addition, we took a conservative approach in extracting data from single cases if strong associations between propofol exposure and the infectious event were reported. 2) Laboratory-based evidence of propofol as a microbiological reservoir was retrieved regarding the frequency of contaminated propofol syringes, vials, or infusion lines used in operating rooms (ORs) or intensive care units (ICUs). 3) Epidemiologic evidence concerning 
the risks of infections associated with propofol was confirmed by case-control, cohort, and clinical trial studies (online Technical Appendix, http://wwwnc.cdc.gov/ EID/article/22/6/15-0376- Techapp1.pdf). 4) Studies on propofol formulations were used for evaluation of the data suggestive of a reduction in microbial growth associated with specific propofol formulations.

We screened 465 abstracts and chose 53 to examine: 25 outbreak reports, 3 reports of single cases, 7 laboratorybased studies on propofol, 10 analytical studies that supported the healthcare effect of contaminated propofol in terms of the risk for infection, and 8 studies of the alternative propofol formulations (Figure 1). We retrieved an additional 5 articles by using references cited in 3 of the initial 53 articles to expand on specific points.

\section{Worldwide Occurrence of Outbreaks Associated with Propofol-Based Anesthesia}

The risk for postoperative infection depends on a variety of factors, including wound class (i.e., clean, clean-contaminated, contaminated, or dirty), the condition of the patient, type and length of surgery, use of antimicrobial drugs, and perioperative events. During the past 2 decades, several episodes of sepsis worldwide have been reported to be associated with propofol administered by syringe injection or used as a continuous infusion $(2-4,6,8-15)$ (Table 1). These cases were reported in industrialized countries; no outbreaks have been documented in developing or low-income countries, such as those in Latin America, Africa, or Asia (Figure 2), likely as a consequence of deficiencies of surveillance programs and poor data acquisition regarding the frequency of contaminated propofol. Propofol-associated infections likely occur in developing countries with relatively higher frequency than in industrialized countries, related to the common problem of economic restraints and reduced use of universal precautions within the healthcare systems, leading to reuse of syringes and use of vials for multiple patients.

Since this anesthetic was introduced, 20 propofolrelated infectious disease outbreaks have been reported worldwide, affecting 144 patients and resulting in 10 deaths; these outbreaks have lasted between 8 hours and 65 days (Table 1). However, many outbreaks related to propofol are likely undocumented and such reports do not reflect ongoing sporadic infections that are likely to be linked to propofol use.

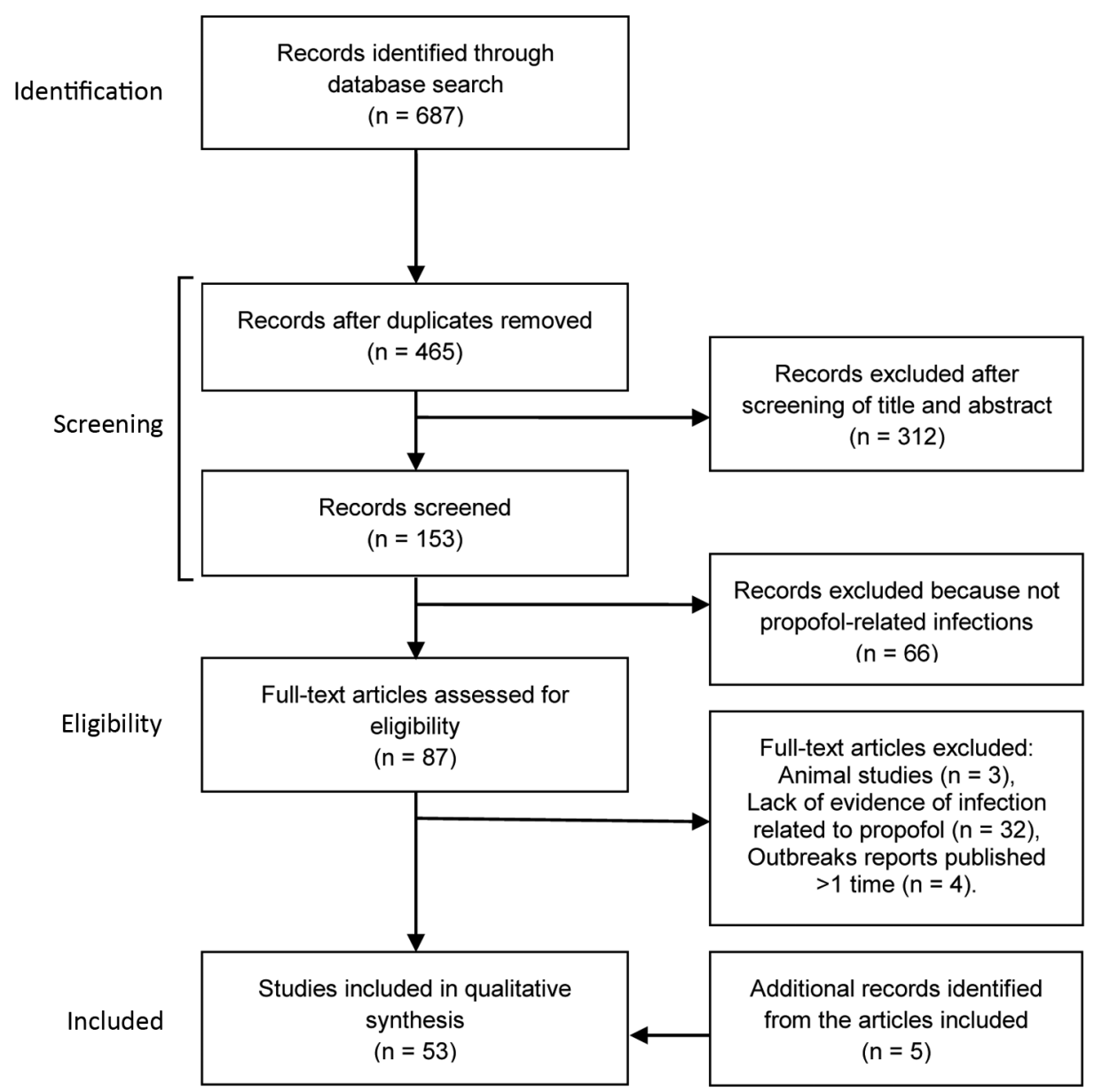

Figure 1. Flowchart of the selection of studies of infectious disease risk associated with contaminated propofol anesthesia, 1989-2014 
Table 1. Summary data of iatragenic disease outbreaks associated with contaminated propofol reported worldwide, 1989-2014*

\begin{tabular}{|c|c|c|c|c|c|c|c|c|c|}
\hline Location† & $\begin{array}{c}\text { No. } \\
\text { outbreaks }\end{array}$ & $\begin{array}{l}\text { Duration, } \\
\text { d } \neq\end{array}$ & Year§ & $\begin{array}{c}\text { Type of } \\
\text { infection }\end{array}$ & Type of surgery & Microorganism & $\begin{array}{c}\text { No. } \\
\text { cases }\end{array}$ & $\begin{array}{l}\text { No. (\%) } \\
\text { deaths }\end{array}$ & Ref. \\
\hline $\begin{array}{l}\text { California, } \\
\text { USA }\end{array}$ & 1 & 8 & 1990 & SSI & ND & $\begin{array}{c}\text { Staphylococcus } \\
\text { aureus }\end{array}$ & 5 & ND & (6) \\
\hline Illinois, USA & 1 & 5 & 1990 & $\begin{array}{c}\mathrm{BSI} \\
\text { endophthalmitis }\end{array}$ & $\begin{array}{l}\text { Endarterectomy, } \\
\text { arthroscopy, } \\
\text { dilation and } \\
\text { curettage }\end{array}$ & Candida albicans & 4 & 0 & (6) \\
\hline Maine, USA & 1 & 2 & 1990 & $\mathrm{BSI}$ & ND & Moraxella osloensis & 2 & 0 & (6) \\
\hline Michigan, USA & 1 & 14 & 1990 & BSI, SSI & $\begin{array}{l}\text { Orthopedics, } \\
\text { gynecology, } \\
\text { biopsy }\end{array}$ & S. aureus & 13 & ND & (6) \\
\hline $\begin{array}{l}\text { Houston, } \\
\text { Texas, USA }\end{array}$ & 1 & 65 & 1990 & $\begin{array}{c}\text { BSI, SSI, } \\
\text { endophthalmitis }\end{array}$ & ND & S. aureus & 16 & $2(12.5)$ & (2) \\
\hline United States & 1 & 11 & 1990 & BSI & $\begin{array}{c}\text { General, urology, } \\
\text { gynecology }\end{array}$ & $\begin{array}{l}\text { Enterobacter } \\
\text { agglomerans }\end{array}$ & 4 & 0 & (2) \\
\hline United States & 1 & 16 & 1992 & BSI, SSI & Orthopedics & $\begin{array}{c}\text { Serratia } \\
\text { marcescens }\end{array}$ & 6 & 0 & (2) \\
\hline United States & 1 & 7 & 1992 & ND & Gynecology & ND & 4 & 0 & (2) \\
\hline Paris, France & 1 & 0.33 & 1994 & $\mathrm{BSI}$ & ND & $\begin{array}{c}\text { Klebsiella } \\
\text { pneumoniae }\end{array}$ & 4 & 0 & $(10)$ \\
\hline $\begin{array}{l}\text { Atlanta, } \\
\text { Georgia, USA }\end{array}$ & 1 & 1 & 1997 & $\mathrm{BSI}$ & $\begin{array}{c}\text { Electroconvulsive } \\
\text { therapy }\end{array}$ & S. aureus & 5 & $1(20)$ & (8) \\
\hline $\begin{array}{l}\text { Reggio Emilia, } \\
\text { Italy }\end{array}$ & 1 & 1 & 2001 & Hepatitis C & Gynecology & $\mathrm{HCV}$ & 5 & 0 & (11) \\
\hline $\begin{array}{l}\text { Toronto, } \\
\text { Ontario, } \\
\text { Canada }\end{array}$ & 1 & ND & 2001 & BSI, SSI & $\begin{array}{l}\text { Orthopedics, } \\
\text { gastrointestinal, } \\
\text { vascular, } \\
\text { neurosurgery, } \\
\text { pulmonary }\end{array}$ & S. marcescens & 7 & $2(28.6)$ & (4) \\
\hline $\begin{array}{l}\text { Berlin, } \\
\text { Germany }\end{array}$ & 1 & ND & 2002 & $\mathrm{BSI}$ & ND & E. cloacae & 4 & $2(50)$ & (3) \\
\hline $\begin{array}{l}\text { Melbourne, } \\
\text { Victoria, } \\
\text { Australia }\end{array}$ & 2 & 2 & 2003 & Hepatitis C & Arthroscopy & $\mathrm{HCV}$ & 6 & ND & (9) \\
\hline $\begin{array}{l}\text { Las Vegas, } \\
\text { Nevada, USA }\end{array}$ & 1 & 2 & 2008 & Hepatitis C & Endoscopy & $\mathrm{HCV}$ & 9\# & $1(11.1)$ & (13) \\
\hline Alicante, Spain & 1 & ND & 2010 & $\begin{array}{c}\text { Systemic } \\
\text { candidiasis, } \\
\text { endophthalmitis }\end{array}$ & Endoscopy & C. albicans & 27 & 0 & $(14)$ \\
\hline $\begin{array}{l}\text { New York, } \\
\text { USA }\end{array}$ & 1 & 2 & 2010 & $\begin{array}{c}\text { Hepatitis C and } \\
\text { B }\end{array}$ & Endoscopy & $\mathrm{HCV}, \mathrm{HBV}$ & 12 & ND & $(12)$ \\
\hline $\begin{array}{l}\text { Rotterdam, the } \\
\text { Netherlands }\end{array}$ & 1 & 2 & 2010 & BSI, SIRS & $\begin{array}{l}\text { Orthopedics, } \\
\text { gynecology }\end{array}$ & $\begin{array}{l}\text { K. pneumoniae, S. } \\
\text { marcescens }\end{array}$ & 7 & $2(28.6)$ & (15) \\
\hline $\begin{array}{l}\text { Hsinchu, } \\
\text { Taiwan }\end{array}$ & 1 & 1 & 2013 & Endotoxemia & $\begin{array}{l}\text { Endoscopy, } \\
\text { colonoscopy }\end{array}$ & ND & 4 & 0 & $(16)$ \\
\hline Total & 20 & & & & & & 144 & $10(9.3)^{\star \star}$ & \\
\hline \multicolumn{10}{|c|}{$\begin{array}{l}\text { *Outbreak, } \geq 2 \text { cases; ND, not described in publication; BSI, bloodstream infection; SSI, surgical site infection; HCV, hepatitis C virus; HBV, hepatitis B } \\
\text { virus; ref., reference; SIRS, systemic inflammatory response syndrome. } \\
\text { tLocation where the outbreak emerged. } \\
\text { †Duration of the outbreak. } \\
\text { \$Year of publication. } \\
\text { TCausative microorganism implicated in outbreak. } \\
\text { \#Results of HCV tests of } 60,000 \text { persons (who underwent procedures requiring anesthesia at the same clinic from March } 1,2004 \text { through January } 11 \text {, } \\
\text { 2008) are pending. The health department identified an additional } 106 \text { infections that could have been linked to the multi-dose vials of propofol. } \\
\text { (http://www.cdc.gov/hepatitis/Outbreaks/HealthcareHepOutbreakTable.htm). } \\
\text { **Death rate was estimated taking into account only the published outbreaks with mortality data reported }(n=108) \text {. }\end{array}$} \\
\hline
\end{tabular}

Outbreaks have been associated with widely diverse types of procedures in both intensive care units (ICUs) and operating rooms (ORs) (Table 1). Although no specific clinical procedure has been causally related to propofolrelated infectious outbreaks, endoscopic procedures have been the most frequently associated with propofol-related infections during the past 20 years.
Contrary to some healthcare perceptions, none of the reported outbreaks to date have been correlated with intrinsic batch-contamination of propofol. Nevertheless, some peerreviewed reports of manufacturing deficiencies exist, as well as $\geq 2$ outbreaks probably linked to intrinsic contamination; however, the latter were published on government Internet sites and therefore are not included in this review. A US 


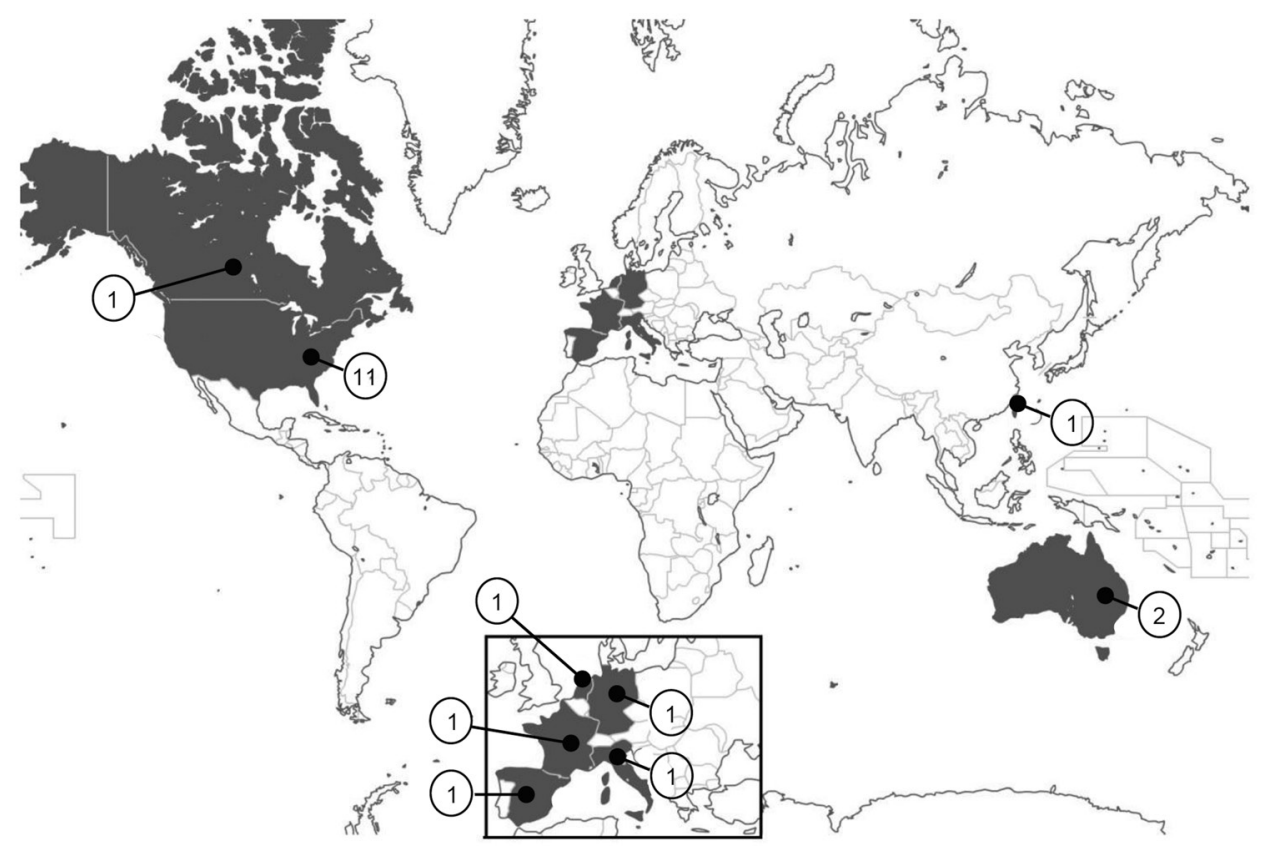

Figure 2. Geographic distribution of propofol-related infectious disease outbreaks worldwide, 1989-2014. Values indicate number of outbreaks for each country.

government report traced 41 cases of infection in 2009 to 1 contaminated batch (http:/www.fda.gov/Safety/Recalls/ArchiveRecalls/2009/ucm172474.htm); 9 other possible cases were traced in Australia in 2014 (https://www.tga.gov.au/ alert/propofol-provive-and-sandoz-propofol-1-emulsioninjection-all-sizes-and-all-batches-update-3).

Distribution of propofal-related outbreaks has been widespread geographically (Figure 2) and temporally (Figure 3). The United States has reported 11 outbreaks, the highest number of outbreaks during the assessed period, averaging 1 every 2 years and accounting for $55 \%$ of all reported outbreaks worldwide. According to the list of healthcare-associated hepatitis B and $\mathrm{C}$ virus (HBV and $\mathrm{HCV}$, respectively) outbreaks reported by the US Centers for Disease Control and Prevention during 2008-2014, the coincident recent exposure to propofol was considered a factor leading to the screening of $>60,000$ patients
(http://www.cdc.gov/hepatitis/Outbreaks/PDFs/Health careInvestigationTable.pdf).

In a 2003 study of the literature on hospital-acquired infections worldwide, Vonberg and Gastmeier calculated a mortality rate of $13.8 \%$ related to administration of propofol (17). The data we collected indicate an estimated mortality rate in propofol-associated infections of $\approx 9.3 \%$ (range $0 \%-50 \%$ ) (Table 1 ). This value only summarizes the current published literature describing propofol-related outbreaks, and thus it may not represent the true magnitude of the problem (2). According to an inspection of data held by AstraZeneca, 345 cases of postoperative infections or febrile syndrome occurred after propofol use in the United States during November 1989-November 2004; unfortunately, data for these cases were archived and not published $(2,18)$.

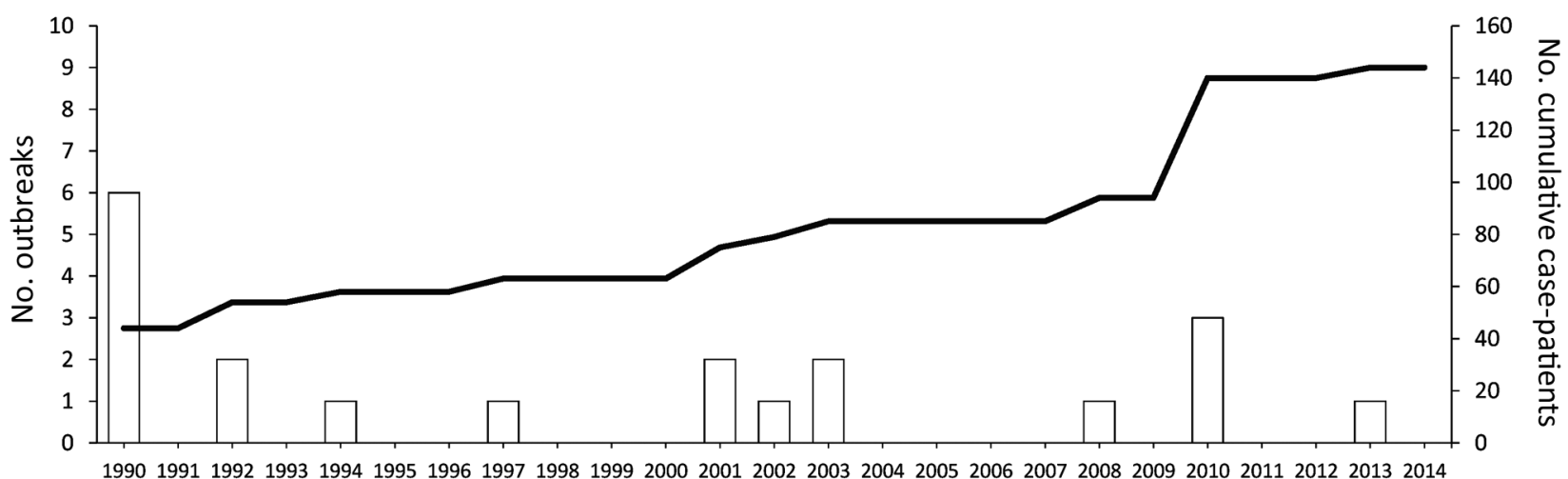

Figure 3. Timing of propofol-related infectious disease outbreaks worldwide during 1989-2014. An outbreak was defined as $\geq 2$ cases. Dashed line indicates cumulative no. case-patients (secondary y-axis). 
Mechanisms of Contamination of Propofol Formulations

Microbiological contamination of propofol lipid emulsions may occur from the environment either during manufacture (intrinsic) or after vial opening (extrinsic), the latter of which is the most frequent. The horizontal transmission of pathogens in anesthesia begins with the breach of handling precautions by anesthesia providers of devices or drugs. Frequently neglected precautions during the induction and maintenance of anesthesia include hand hygiene and protection against incidental propofol contact with the environment (19-21). In addition, surreptitious use of IV anesthetics by drug-addicted healthcare workers could raise the risk for extrinsic contamination (22). Other factors that may potentially affect the sterility of propofol in clinical use include preparation of multiple syringes for use throughout the day; re-use of vials, syringes, or infusion-pump lines on $>1$ patient; use of opened ampules longer than recommended by the manufacturer; and failure to wear sterile gloves during handling of propofol and to dispose of them after each contact.

The most common reservoirs associated with extrinsic contamination of propofol are syringes or micro-droppers, vials, and IV stopcock dead space. Syringes or micro-droppers have been implicated in most outbreaks (23-27). Propofol vials have been demonstrated to be a reservoir for microbes when contents are exposed to the environment (28). Delays in administration after propofol vials have been opened are a recognized risk factor; the degree of contamination of an opened vial may increase by $20 \%-26 \%$ after 12 hours (29). Propofol is available in vials of various volumes; a typical $20-\mathrm{mL}$ vial contains $200 \mathrm{mg}$, and 50 - and $100-\mathrm{mg}$ vials are available. It is believed that administering a dose $>200 \mathrm{mg}$ to an adult in an OR will increase the probability of using an additional vial as a multi-dose vial for $\geq 1$ patients. IV stopcock dead space has been shown to provide a potential route of entry for pathogenic, multidrug-resistant bacteria in infusion lines $(20,27)$.

A number of microorganisms are associated with propofol in clinical- and laboratory-based studies at varying frequencies (Table 2). We report the specific pathogens that have been associated in several outbreaks $(2-4,6,8-10,12$ $15,30,31$ ), as well as all of the transmissible microorganisms that have been observed in contaminated propofol in

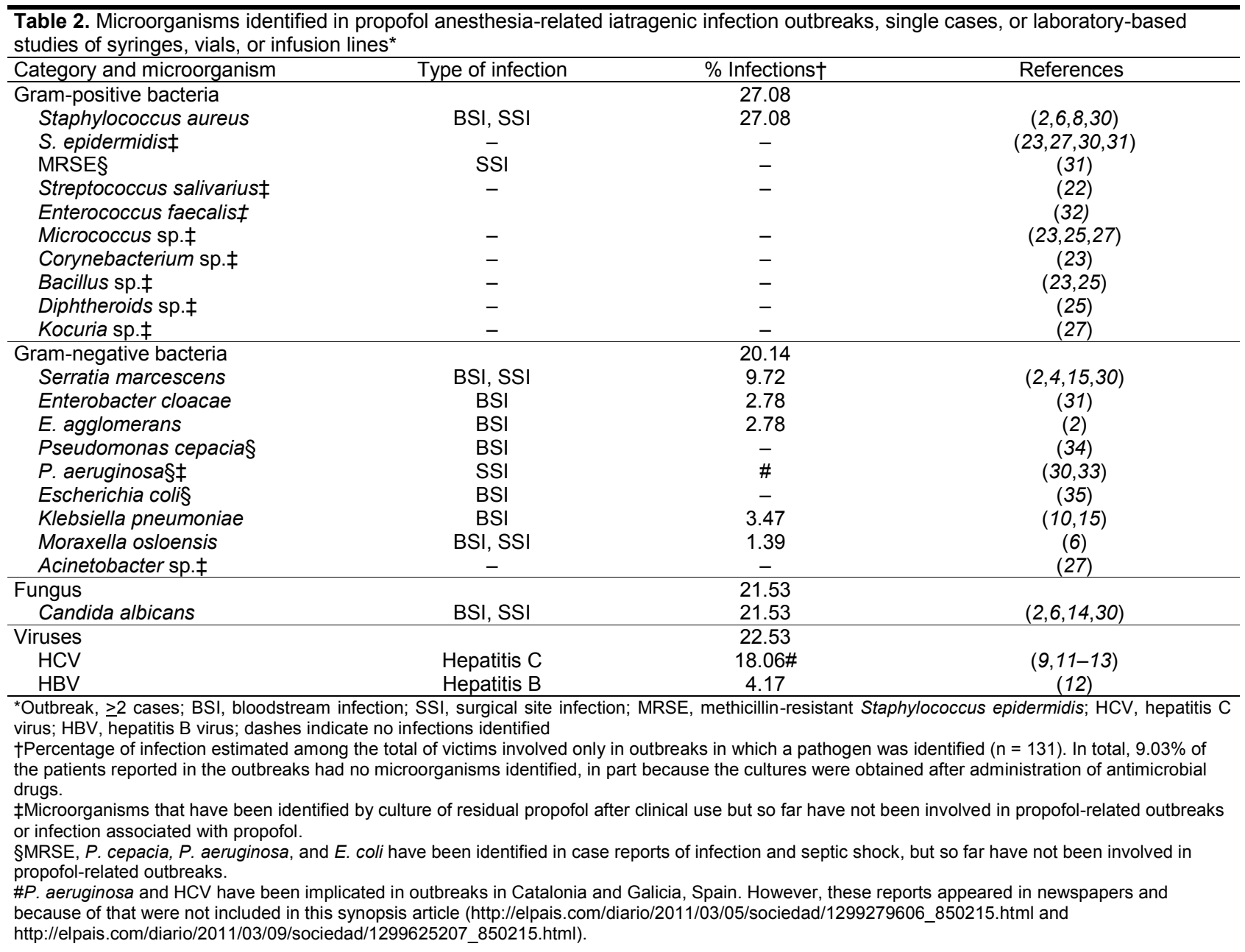


syringes, vials, and infusion lines $(23,25,27,30,32)$. We also describe 3 reported cases of septic shock related to propofol $(33,34)$.

Propofol is an excellent medium not only for bacterial growth but also for fungal infections, which have been associated with propofol use particularly when poor hygienic standards are observed during the administration. Viral infections with HCV and HBV have also been demonstrated, possibly explained by the viral stability offered by propofol emulsions $(9,11,13)$. Overall, $\approx 23 \%$ of the published infection outbreaks associated with propofol were caused by HCV (18.1\%) and HBV (4.2\%); $21.5 \%$ by Candida albicans; and $47.2 \%$ by bacteria (gram-positive $27.1 \%$, gram-negative $20.1 \%$ ). In the remaining reports, no microorganisms were identified, possibly as a consequence of concurrent antimicrobial drug therapy. The most frequent pathogens associated with propofol-related outbreaks, in order of frequency, were Staphylococcus aureus (39/144), Candida albicans (31/144), and HCV (26/144).

Laboratory-based (Table 3) and epidemiologic (online Technical Appendix Table 1) microbiological studies have demonstrated that the production of bacterial endotoxins is greatly enhanced by propofol solutions. Case reports of endotoxemia associated with the use of contaminated propofol have also been published $(5,34,35)$.

\section{Frequency of Contaminated Propofol Used in ICUs and ORs}

Microbiological observations of opened propofol vials were reported in the first studies that identified bacterial growth in propofol, and observational studies on propofol formulations have determined the proportion of extrinsic contamination (Table 3). In 1994, Farrington et al. established an incidence rate of $6 \%$ (3/50) of contaminated propofol syringes in an ICU (31). Webb et al. retrospectively observed similar results in a different ICU setting with an incidence of 5.9\% (18/302) (23). Soong observed a lower propofol contamination incidence $(3.0 \%)$ in ORs and also noted an association between postoperative infections and vials from which multiple patients were medicated (24); Bach et al. found similar results (30). In 1995, McHugh and Roper reported an incidence of $6.3 \%$ (16/254) of infection when propofol was administered from vials but did not find that delays in the administration of propofol were associated in any increased likelihood of bacterial contamination (25). Cole et al. recorded the incidence of contamination as high as $17.3 \%(26 / 150)$ in propofol found in stopcock dead space (27).

The distribution of instructions for aseptic measures for handling propofol has shown to reduce the rate of contaminated propofol. Lorenz et al. reported that after a specific protocol for handling propofol was introduced and adhered to, a reduction in extrinsic contamination was achieved when compared with only adhering to the manufacturer's recommendations (8.8\% versus $11.3 \%)$ (26). That protocol included additional aseptic precautions, such as refilling empty syringes for use on multiple patients by using a 3-way stopcock and replacing only the infusion line to the patient. Data from a study performed in a high-complexity hospital in Cali, Colombia, showed substantial microbial growth of

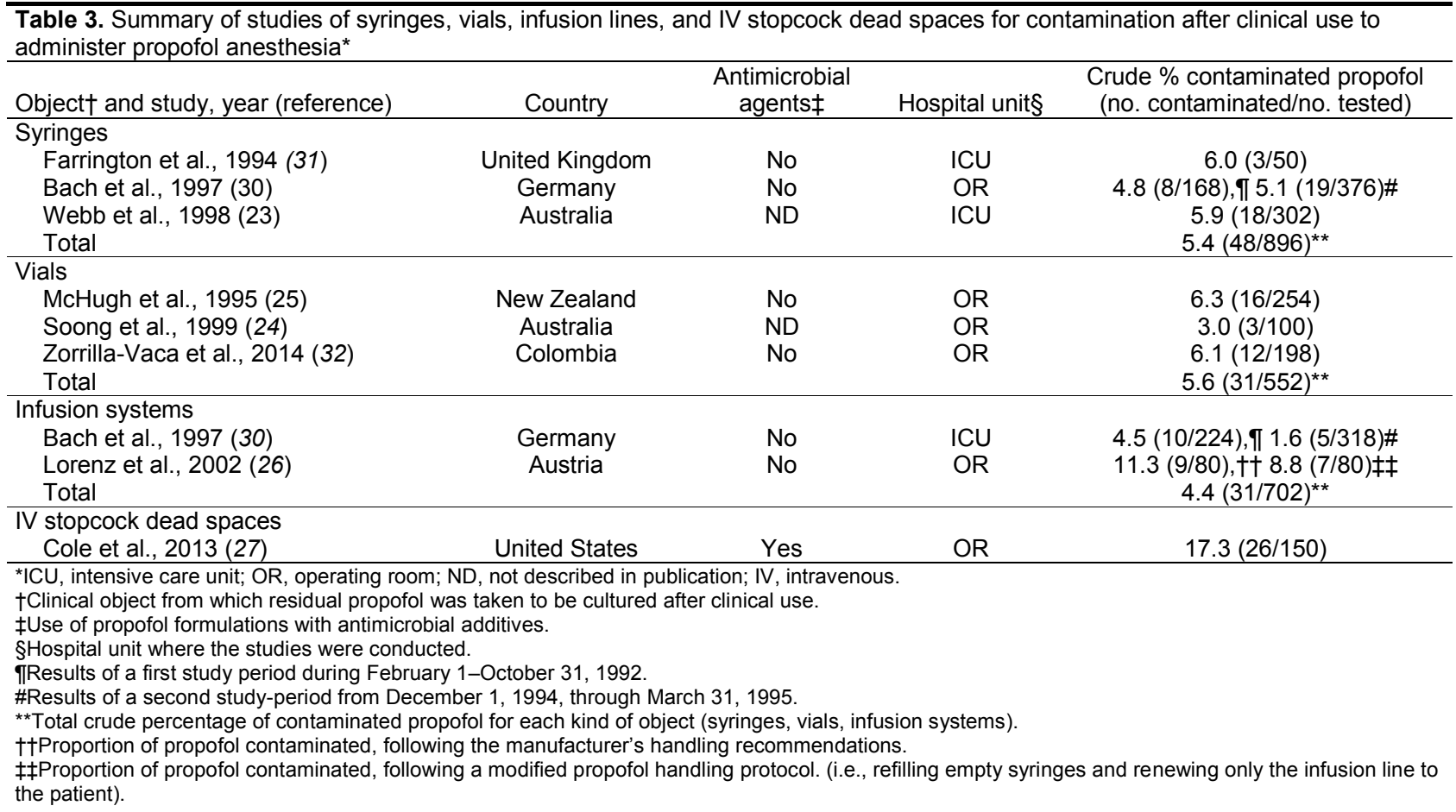


$6.1 \%(12 / 198)$ in residual propofol vials used in ORs at a tertiary hospital in Cali (32).

By collating the incidences of contaminated propofol in containers or devices, the data suggest that it is more common to encounter contaminated previously used vials of propofol $(5.6 \%, 31 / 552)$ than in used syringes $(5.4 \%$, $48 / 896)$ and infusion systems (4.4\%, 31/702). Similarly, analyzed by hospital location, the percentage of contaminated propofol is greater in ORs $(7.3 \%, 103 / 1,405)$ than in ICUs $(4.0 \%, 36 / 894)$, correlating well with the expected prevalence of opened vials and syringes used for bolus injections of propofol for multiple patients in the OR compared with those in the ICUs.

Risk for Infection Data Derived from Analytical Studies After we reviewed the initial microbiological studies, our interest increased in ascertaining potential links between the use of propofol infusions and the incidence of infections and sepsis after surgery. We analyzed 10 epidemiologic studies (Table 4; online Technical Appendix Table 1); of these, 4 assessed the associations with infection when practitioners followed manufacturers' instructions for propofol handling, 5 assessed the association with infection when practitioners did not follow instructions, and 1 did not report on this issue. Studies following manufacturers' precautions stated such within the articles, but the degree of compliance of such precautions was not documented (online Technical Appendix Table 2). In 4 of 5 studies (80\%) during which practitioners did not follow handling precautions, high infection risk was noted. In 4 studies in which precautions were followed, 2 (50\%) scored above the significant risk threshold (online Technical Appendix Table 1). These findings underscore the controversy surrounding the utility of existing handling protocols and demonstrates the continued high potential of propofol as a causal factor of iatrogenic infection. Other authors have explain the susceptibility to infection because of the attenuation of the immunological activity caused by propofol infusions. More studies of specific handling protocols are required before a significant risk reduction is clearly observed. We developed an algorithmic approach that shows certain crucial measures to prevent future propofol-related outbreaks of infections (Figure 4); this approach was based on our analyses and summaries of the epidemiologic and clinical data selected.

\section{Proposed Propofol Formulations without Risk for Infection}

There are currently no propofol formulations without infection risk; however, several investigators have advocated the use of antimicrobial additives. As required by the FDA, the efficacy of such additives must retard microorganism growth to $<10$-fold at 24 hours after extrinsic contamination of propofol (1); many suggested antimicrobial agents have been rejected because of their poor efficacy, additional side effects, or higher costs (1). The fact that propofol is a lipid emulsion poses problems when additives are considered because admixture with other substances, especially charged species with differing

\begin{tabular}{|c|c|c|c|c|c|c|}
\hline $\begin{array}{l}\text { Followed manufacturers' } \\
\text { precautions, study, year }\end{array}$ & Type of study & $\begin{array}{l}\text { Preservative- } \\
\text { free propofol† }\end{array}$ & $\begin{array}{l}\text { Other agents compared } \\
\text { with propofol }\end{array}$ & $\begin{array}{l}\text { Type of } \\
\text { infection }\end{array}$ & $\begin{array}{l}\text { Hospital } \\
\text { unit }\end{array}$ & Association§ \\
\hline \multicolumn{7}{|l|}{ Yes } \\
\hline Seeberger et al., 1998 & $\begin{array}{l}\text { Retrospective } \\
\text { cohort }\end{array}$ & Yes & Thiopentone & Sepsis & OR & No \\
\hline Shimizu et al., 2010 & Cohort & ND & Sevoflurane & SSI & OR & Yes \\
\hline Haddad et al., 2011 & Nested cohort & Yes & ND & Multipleף & $\mathrm{ICU}$ & Yes \\
\hline Moehring et al., 2014 & Case-control & ND & Fentanyl & $\mathrm{BSI}$ & $\mathrm{ICU}$ & No \\
\hline \multicolumn{7}{|l|}{ No } \\
\hline Bennett et al., 1995. (2) & $\begin{array}{l}\text { Case-control } \\
\text { and cohort }\end{array}$ & Yes & Sufentanil, alfentanil & BSI, SSI & OR & Yes \\
\hline Henry et al., 2001 (4) & Case-control & Yes & ND & BSI, SSI & OR & Yes \\
\hline McNeil et al., 1999 & Cohort & Yes & $\begin{array}{l}\text { Sufentanil, fentanyl, } \\
\text { midazolam, vecuronium }\end{array}$ & $\begin{array}{c}\text { Fungemia, } \\
\text { endophthal } \\
\text { mitis }\end{array}$ & OR & Yes \\
\hline Sebert et al., 2002. & Case-control & ND & ND & BSI & OR & No \\
\hline Muller et al., 2010 (15) & $\begin{array}{c}\text { Retrospective } \\
\text { cohort }\end{array}$ & ND & Fentanyl, midazolam & BSI, SIRS & OR & Yes \\
\hline \multicolumn{7}{|l|}{ ND } \\
\hline Kontopoulou et al., 2012 & Case-control & ND & ND & $\mathrm{BSI}$ & $\mathrm{ICU}$ & Yes \\
\hline \multicolumn{7}{|c|}{$\begin{array}{l}\text { *Complete data and full references are available in the online Technical Appendix (http://wwwnc.cdc.gov/EID/article/22/6/15-0376-Techapp1.pdf); OR, } \\
\text { operating room; ICU, intensive care unit; BSI, bloodstream infection; SSI, Surgical site infection; ND, not described in publication; SIRS, systemic } \\
\text { inflammatory response syndrome. } \\
\text { †Use of propofol without antimicrobial additives. } \\
\text { †Hospital unit where the studies were conducted. } \\
\text { §Conclusion of the analytical study regarding the association between propofol exposure and infectious events. }\end{array}$} \\
\hline
\end{tabular}




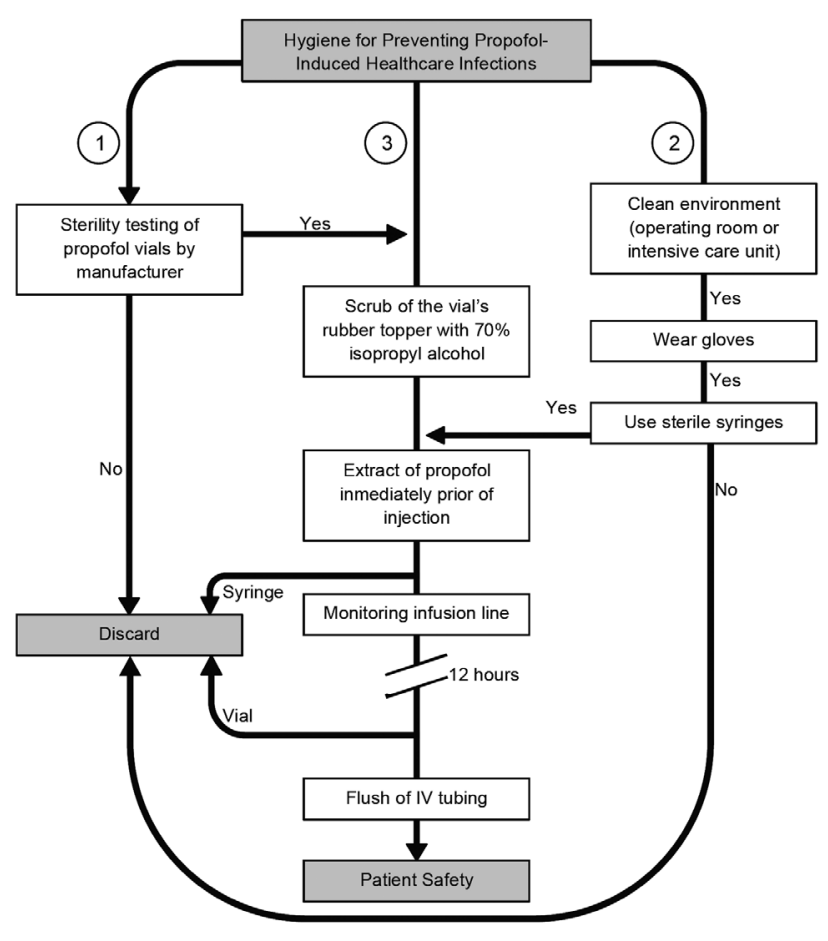

Figure 4. Algorithm for helping reduce the likelihood of infectious disease events when using propofol. To avoid intrinsic contamination, sufficient quality control during the manufacturers' process is required (1). Personnel must be aware of the importance of performing healthcare procedures in a clean environment and the use of gloves and sterile syringes for anesthetic procedures. Syringes and needles must never be reused (2). Also, the aseptic technique for administration of propofol includes cleaning of the rubber bung, if present, with isopropyl alcohol, leaving it to dry. Propofol should be drawn up immediately before its use and not left standing. Intravenous (IV) infusion lines and stopcock dead spaces should be completely flushed to ensure no residual propofol remains. Vials must be discarded after opening for single use, no matter the amount of the remainder (3).

partition coefficients, can interact with either the lipid phase or the emulsifying agents, resulting in emulsion destabilization. Older and newer advances on the use of additives are described in Table 5, which includes the scientific progress related to patients, clinical trials, original articles, and brief reports.

\section{Propofol with EDTA}

As an antimicrobial ion chelator, EDTA exerts its effect by removing divalent and trivalent metal cations, causing rupture of the microbial cell membrane by loss of control of osmotic pressure gradients. This combination is approved by the FDA; clinical trials demonstrated antimicrobial efficacy and safety in humans $(18,36)$. For manufacturers, EDTA is the most broadly incorporated agent in combination with propofol formulations. Despite its widespread use, some controversy remains over its selection as the optimal additive (37). Moreover, in several developing countries, cost remains a considerable limiting factor for the use of EDTA-containing propofol formulations (A. Zorrilla-Vaca et al., unpub. data).

\section{Fospropofol Disodium}

A newly introduced agent, fospropofol disodium, is a water-soluble pro-drug of propofol that currently has a small evidence base for its use of 3 published clinical trials in the literature; in these studies, fospropofol was assessed for use in sedation for colonoscopies, bronchoscopies, and coronary artery bypass graft surgery, and showed an acceptable safety profile (38). The advantage of this drug in reducing the risk for infectious events is that it does not have a lipophilic formulation that would support bacterial growth. Nonetheless, the drug has some disadvantages that could discourage its use, such as transient paresthesias and pruritis in the perineal and perianal regions (38).

\section{Anesthetic Mixtures}

Pain on injection is a common side effect of propofol. Anesthesiologists use a variety of strategies to reduce this, such as the addition of $1-2 \mathrm{~mL}$ of lidocaine to the propofol before injection. Lidocaine, like other amide local anesthetics, has bacteriostatic properties, which could theoretically reduce the chances of infection (29). It is, however, not currently known whether lidocaine has sufficient antimicrobial effect to make a clinical difference in infection rates.

\section{Other Additives}

Benzyl alcohol at concentrations of $\leq 2 \%$ has been used as a preservative agent in propofol formulations (39). Despite its bacteriostatic activity, benzyl alcohol used in propofol formulations is limited by its toxicity and instability in the combination. Other additives, such as phenylmercuric nitrate, phenylmercuric acetate, chlorobutanol, and phenol have been studied experimentally with propofol; however, all of these agents were rejected because of their potential toxicity. The sodium metabisulfite-containing formulation, created originally with the aim of reducing the pain of propofol injection, has been shown to possess preservative properties. Unfortunately, it has a labeled $\mathrm{pH}$ from 4.5 to 6.4 , which is different from the FDA requirement of a $\mathrm{pH}$ of 6-8.5 for propofol (1). The nonlipid nanoemulsion and EmulSiv filter are the most recent alternative propofol formulations (40). In recent studies, these formulations of propofol have attained a level of antimicrobial activity above that observed with propofol with EDTA (40). Costs are currently a limiting factor for their use, but these 2 options seem to provide some promise for the future if production costs decline. 
Table 5. Description of advantages and disadvantages of each formulation of propofol related to contamination and iatragenic infection*

\begin{tabular}{|c|c|c|c|c|}
\hline $\begin{array}{l}\text { Propofol } \\
\text { formulation }\end{array}$ & Settings & Advantages & Disadvantages & $\begin{array}{c}\text { FDA } \\
\text { approval }\end{array}$ \\
\hline $\begin{array}{l}\text { Propofol with } \\
\text { EDTA }\end{array}$ & $\begin{array}{c}\text { Antimicrobial } \\
\text { activity }\end{array}$ & $\begin{array}{c}\text { This mixture with propofol at } 0.005 \% \text { wt/vol } \\
\text { concentration has demonstrated microbial growth } \\
\text { to be retarded to } \geq 1 \text { log CFUs ( } 36) \text {, of nearly } 20 \\
\text { microorganisms, including } 7 \text { Gram-positive } \\
\text { bacteria, } 10 \text { Gram-negative bacteria, and } 3 \text { yeasts } \\
\text { (18). Further, incidence of propofol-related } \\
\text { infection declined from } 39 \text { to } 9 \text { infections per year } \\
\text { in the USA, after the introduction of EDTA into } \\
\text { clinical use in } 1996 \text { (18). }\end{array}$ & $\begin{array}{c}\text { Decreases serum ionized calcium } \\
\text { levels, although statistically significant, } \\
\text { has apparently no clinical effect (time } \\
\text { to complete recovery, } \mathrm{p}=0.77 \text { [37]). } \\
\text { Also, EDTA is nephrotoxic at high } \\
\text { doses }(2-3 \mathrm{~g} / \mathrm{d}) \text {. Concern that use of } \\
\text { an antimicrobial may cause health } \\
\text { personnel to relax on aseptic handling } \\
\text { practices (1). }\end{array}$ & Yes \\
\hline $\begin{array}{l}\text { Fospropofol } \\
\text { disodium }\end{array}$ & $\begin{array}{l}\text { Nonlipophilic } \\
\text { preparation }\end{array}$ & $\begin{array}{c}\text { Because of water solubility, eliminates some of } \\
\text { the known lipid emulsion-associated } \\
\text { disadvantages of propofol, including the risk for } \\
\text { infection (38). }\end{array}$ & $\begin{array}{l}\text { Minor side effects (e.g., paresthesia, } \\
\text { hypotension). The prolonged onset of } \\
\text { action of fospropofol }(\approx 4-13 \mathrm{~min}, \\
\text { because of it must first undergo } \\
\text { metabolism to propofol) compared with } \\
\text { the prodrug propofol }(\approx 40 \mathrm{~s}) \text {. Allergies } \\
\text { caused by the accumulation of a } \\
\text { phosphate-ester component }(38) \text {. }\end{array}$ & Yest \\
\hline
\end{tabular}

\begin{tabular}{|c|c|c|c|c|}
\hline $\begin{array}{l}\text { Propofol and } \\
\text { lidocaine }\end{array}$ & $\begin{array}{l}\text { Bacteriostatic } \\
\text { activity }\end{array}$ & $\begin{array}{c}\text { Experimentally causes loss of viability of several } \\
\text { strains }(29) \text {. }\end{array}$ & $\begin{array}{l}\text { Has no sufficient retarding effect. } \\
\text { Possibilities of micelle formation exist. }\end{array}$ & No \\
\hline Benzyl alcohol & $\begin{array}{l}\text { Antimicrobial } \\
\text { activity }\end{array}$ & $\begin{array}{c}\text { At low concentrations of } \geq 2 \% \text {, has been used as a } \\
\text { preservative agent. }\end{array}$ & Toxicity and presumed instability. & No \\
\hline $\begin{array}{l}\text { Sodium } \\
\text { metabisulfite }\end{array}$ & $\begin{array}{l}\text { Antimicrobial } \\
\text { activity }\end{array}$ & $\begin{array}{c}\text { Reduces the pain of propofol injection and has } \\
\text { preservative properties. }\end{array}$ & $\begin{array}{c}\text { Has a labeled } \mathrm{pH} \text { of } 4.5-6.4 \text {, which is } \\
\text { different from the required } \mathrm{pH} \text { for } \\
\text { propofol }(6-8.5)(1) \text {. }\end{array}$ & No \\
\hline EmulSiv filter & Filter & $\begin{array}{c}\text { Use of the } 0.45 \mu \text { m-rated filter is purported to } \\
\text { provide protection from accidental microbial } \\
\text { contamination, particulate contamination and } \\
\text { entrained air while maintaining the integrity of the } \\
\text { emulsion (40). }\end{array}$ & High costs, not currently available. & No \\
\hline $\begin{array}{l}\text { Nonlipid } \\
\text { propofol } \\
\text { nanoemulsion }\end{array}$ & $\begin{array}{l}\text { Nonlipophilic } \\
\text { preparation }\end{array}$ & $\begin{array}{l}\text { Replaces soybean lecithin with polyethylene } \\
\text { glycol } 660 \text { hydroxystearate as propofol carrier } \\
(40) \text {. }\end{array}$ & High costs, not currently available. & No \\
\hline
\end{tabular}

\section{Discussion}

Contaminated propofol has been implicated in several episodes of iatrogenic infection in both the outpatient and inpatient settings, as well as in both surgical and nonsurgical patients $(2,6,11,12,15)$. The risk for infection arises principally because the lipophilic nature of propofol supports microbial growth when the formulation becomes contaminated $(2,6)$. In addition, the method of intravenous administration and the preservative-free preparations still used in many countries have been implicated in promoting infection with propofol use.

More than 2 decades have elapsed since the first outbreaks of contaminated propofol-related infection emerged in the United States (6), and incidents of contaminationrelated infections persist, despite the introduction of antimicrobial formulations. Contamination and infections associated with propofol have been most commonly reported in industrialized countries, but it is likely that this phenomenon is secondary to a lack of surveillance of propofol contamination in developing countries. Management of this risk for contamination and infection can be approached by continued medical education regarding patient safety. A lack of adherence to the manufacturers' guidelines appears to have been a causative factor in most of the episodes reported worldwide. The adherence to strict aseptic handling protocols is mandatory and more education efforts (e.g., the One and Only Campaign, http://www.oneand onlycampaign.org/) are needed to generate awareness in the healthcare community of the importance of proper propofol practices.

In summary, healthcare-associated infections linked with contaminated propofol constitute a complex public health issue that requires a multifaceted approach. Further efforts in surveillance and research are required to reduce the potential harm from contaminated propofol. Healthcare practitioners must focus on standard hygienic measures and the increased use of approved antimicrobial propofol formulations. Following these simple tenets, the risk for in-use contamination would be lowered and the safety use profile for propofol would greatly improve. 


\section{Acknowledgments}

We thank Alejandro Núñez for his help in retrieving articles.

Mr. Zorrilla-Vaca is a distinguished medical student at Universidad del Valle, Cali, Colombia, and trainee in anesthesiology at the Johns Hopkins University School of Medicine, Baltimore, MD, USA. His research interests are patient outcomes after general and regional anesthesia with particular focus on infectious and neurological complications.

\section{References}

1. Thompson KA, Goodale DB. The recent development of propofol (DIPRIVAN). Intensive Care Med. 2000;26:S400-4. http://dx.doi.org/10.1007/PL00003783

2. Bennett SN, McNeil MM, Bland LA, Arduino MJ, Villarino ME, Perrotta DM, et al. Postoperative infections traced to contamination of an intravenous anesthetic, propofol. N Engl J Med. 1995;333: 147-54. http://dx.doi.org/10.1056/NEJM199507203330303

3. Weist K, Wilbrandt B, Herm T, Halle E, Melzer C, Rüden H. Severe cases of sepsis in an outpatient clinic caused by contaminated intravenous propofol (abstract). DGHM-Tagung Heidelb. 2002.

4. Henry B, Plante-Jenkins C, Ostrowska K. An outbreak of Serratia marcescens associated with the anesthetic agent propofol. Am J Infect Control. 2001;29:312-5. http://dx.doi.org/10.1067/ mic. 2001.117043

5. Arduino MJ, Bland LA, McAllister SK, Aguero SM, Villarino ME, McNeil MM, et al. Microbial growth and endotoxin production in the intravenous anesthetic propofol. Infect Control Hosp Epidemiol. 1991;12:535-9. http://dx.doi.org/10.2307/30145228

6. Centers for Disease Control and Prevention. Postsurgical infections associated with an extrinsically contaminated intravenous anesthetic agent - California, Illinois, Maine, and Michigan, 1990. MMWR Morb Mortal Wkly Rep. 1990;39:426-7.

7. King CA, Ogg M. Safe injection practices for administration of propofol. AORN J. 2012;95:365-72. http://dx.doi.org/10.1016/ j.aorn.2011.06.009

8. Kuehnert MJ, Webb RM, Jochimsen EM, Hancock GA, Arduino MJ, Hand S, et al. Staphylococcus aureus bloodstream infections among patients undergoing electroconvulsive therapy traced to breaks in infection control and possible extrinsic contamination by propofol. Anesth Analg. 1997;85:420-5.

9. Tallis GF, Ryan GM, Lambert SB, Bowden DS, McCaw R, Birch CJ, et al. Evidence of patient-to-patient transmission of hepatitis $\mathrm{C}$ virus through contaminated intravenous anaesthetic ampoules. J Viral Hepat. 2003;10:234-9. http://dx.doi.org/10.1046/ j.1365-2893.2003.00424.x

10. Veber B, Gachot B, Bedos JP, Wolff M. Severe sepsis after intravenous injection of contaminated propofol. Anesthesiology. 1994;80:712-3. http://dx.doi.org/10.1097/00000542199403000-00050

11. Massari M, Petrosillo N, Ippolito G, Solforosi L, Bonazzi L, Clementi M. Transmission of hepatitis $\mathrm{C}$ virus in a gynecological surgery setting. J Clin Microbiol. 2001;39:2860-3. http://dx.doi.org/10.1128/JCM.39.8.2860-2863.2001

12. Gutelius B, Perz JF, Parker MM, Hallack R, Stricof R, Clement EJ, et al. Multiple clusters of hepatitis virus infections associated with anesthesia for outpatient endoscopy procedures. Gastroenterology. 2010;139:163-70. http://dx.doi.org/ 10.1053/ j.gastro.2010.03.053

13. Acute hepatitis $\mathrm{C}$ virus infections attributed to unsafe injection practices at an endoscopy clinic-Nevada, 2007. MMWR Morb Mortal Wkly Rep. 2008;57:513-7.

14. Aparicio J, Sánchez-Paya J, Merino E, Martínez J, Ruiz F, Compañy L, et al. Outbreak of systemic candidiasis infection associated with propofol administration in an endoscopy unit (abstract) [in Spanish]. Endoscopy. 2010;42:A29. http://dx.doi.org/ $10.1055 / \mathrm{s}-2010-1268647$

15. Muller AE, Huisman I, Roos PJ, Rietveld AP, Klein J, Harbers JB, et al. Outbreak of severe sepsis due to contaminated propofol: lessons to learn. J Hosp Infect. 2010;76:225-30. http://dx.doi.org/ 10.1016/j.jhin.2010.06.003

16. Chen SH, Kung CC, Fung ST. Endotoxemia due to propofol contamination in four consecutive patients. J Formos Med Assoc. 2014;113:328-9. http://dx.doi.org/10.1016/j.jfma.2013.08.012

17. Vonberg RP, Gastmeier P. Hospital acquired infections related to contaminated substances. J Hosp Infect. 2007;65:15-23. http://dx.doi.org/10.1016/j.jhin.2006.09.018

18. Jansson JR, Fukada T, Ozaki M, Kimura S. Propofol EDTA and reduced incidence of infection. Anaesth Intensive Care. 2006;34:362-8.

19. Munoz-Price LS, Riley B, Banks S, Eber S, Arheart K, Lubarsky DA, et al. Frequency of interactions and hand disinfections among anesthesiologists while providing anesthesia care in the operating room: induction versus maintenance. Infect Control Hosp Epidemiol. 2014;35:1056-9. http://dx.doi.org/ $10.1086 / 677154$

20. Loftus RW, Koff MD, Burchman CC, Schwartzman JD, Thorum V, Read ME, et al. Transmission of pathogenic bacterial organisms in the anesthesia work area. Anesthesiology. 2008; 109:399-407. http://dx.doi.org/10.1097 ALN.0b013e318182c855

21. Loftus RW, Patel HM, Huysman BC, Kispert DP, Koff MD, Gallagher JD, et al. Prevention of intravenous bacterial injection from health care provider hands: the importance of catheter design and handling. Anesth Analg. 2012;115:1109-19. http://dx.doi.org/10.1213/ANE.0b013e31826a1016

22. Maki DG, Klein B, McCormick R, Alvarado C, Stolz S, Zilz M. Nosocomial Pseudomonas pickettii bacteremias traced to narcotic tampering. JAMA. 1991;265:981-6. http://dx.doi.org/10.1001/ jama.1991.03460080051031

23. Webb SA, Roberts B, Breheny FX, Golledge CL, Cameron PD, van Heerden PV. Contamination of propofol infusions in the intensive care unit: incidence and clinical significance. Anaesth Intensive Care. 1998;26:162-4.

24. Soong WA. Bacterial contamination of propofol in the operating theatre. Anaesth Intensive Care. 1999;27:493-6.

25. McHugh GJ, Roper GM. Propofol emulsion and bacterial contamination. Can J Anaesth. 1995;42:801-4. http://dx.doi.org/ 10.1007/BF03011181

26. Lorenz IH, Kolbitsch C, Lass-Flörl C, Gritznig I, Vollert B, Lingnau W, et al. Routine handling of propofol prevents contamination as effectively as does strict adherence to the manufacturer's recommendations. Can J Anaesth. 2002;49:347-52. http://dx.doi.org/10.1007/BF03017321

27. Cole DC, Baslanti TO, Gravenstein NL, Gravenstein N. Leaving more than your fingerprint on the intravenous line: a prospective study on propofol anesthesia and implications of stopcock contamination. Anesth Analg. 2015;120:861-7. http://dx.doi.org/10.1213/ANE.0b013e318292ed45

28. Finkelstein A, Lokhandwala BS, Pandey NS. Particulate contamination of an intact glass ampule. Anesthesiology. 1990; 73:362-3. http://dx.doi.org/10.1097/00000542-199008000-00044

29. Aydin ON, Aydin N, Gultekin B, Ozgun S, Gurel A. Bacterial contamination of propofol: the effects of temperature and lidocaine. Eur J Anaesthesiol. 2002;19:455-8. http://dx.doi.org/10.1017/ S026502150200073X

30. Bach A, Motsch J, Schmidt H, Böttiger BW, Böhrer H, Martin $\mathrm{H}$, et al. In-use contamination of propofol. A clinical study. Eur J Anaesthesiol. 1997;14:178-83. http://dx.doi.org/10.1097/ 00003643-199703000-00010 
31. Farrington M, McGinnes J, Matthews I, Park GR. Do infusions of midazolam and propofol pose an infection risk to critically ill patients? Br J Anaesth. 1994;72:415-7. http://dx.doi.org/10.1093/ $\mathrm{bja} / 72.4 .415$

32. Zorrilla-Vaca A, Escandon-Vargas K, Brand-Giraldo V, Leon T, Herrera M, Payan A. Bacterial contamination of propofol vials used in operating rooms of a third-level hospital. Am J Infect Control. 2015;44:e1-e3. http://dx.doi.org/10.1016/ j.ajic.2015.08.009

33. Abdelmalak BB, Bashour CA, Yared JP. Skin infection and necrosis after subcutaneous infiltration of propofol in the intensive care unit. Can J Anaesth. 2008;55:471-3. http://dx.doi.org/10.1007/BF03016315

34. Yu HP, Tang GJ, Liaw WJ, Yien HW, Lee TY. Pseudomonas cepacia induced septic shock after propofol - a case report. Acta Anaesthesiol Sin. 2000;38:53-6.

35. Kim YD, Lee HK, Jwa YJ, Jung SK, Um TH, Cho CR, et al. A case of septic shock caused by Escherichia coli after intravenous injection of contaminated propofol [in Korean]. Infect Chemother. 2010;42:296-8. http://dx.doi.org/10.3947/ic.2010.42.5.296

36. Fukada T, Ozaki M. Microbial growth in propofol formulations with disodium edetate and the influence of venous access system dead space. Anaesthesia. 2007;62:575-80. http://dx.doi.org/10.1111/j.1365-2044.2007.05002.x

37. Cohen IT, Hannallah RS, Goodale DB. The clinical and biochemical effects of propofol infusion with and without EDTA for maintenance anesthesia in healthy children undergoing ambulatory surgery. Anesth Analg. 2001;93:106-11. http://dx.doi.org/10.1097/00000539-200107000-00023

38. Mahajan B, Kaushal S, Mahajan R. Fospropofol. J Pharmacol Pharmacother. 2012;3:293-6. http://dx.doi.org/10.4103/ 0976-500X.99457

39. Minogue SC, Sun DA. Bacteriostatic saline containing benzyl alcohol decreases the pain associated with the injection of propofol. Anesth Analg. 2005;100:683-6. http://dx.doi.org/10.1213/ 01.ANE.0000148617.98716.EB

40. Lourenço FR, Kikuhi IS, Yamamoto RN, Pinto TJA. Extrinsic contamination of propofol non-lipid nanoemulsion [in Spanish]. Rev Bras Farm. 2012;93:504-9.

Address for correspondence: Andrés Zorrilla-Vaca, Faculty of Health, Universidad del Valle, Calle 4B \# 36-00, Cali, 760026, Colombia; email: andres.zorrilla@correounivalle.edu.co

\section{WORLD HEALTH DAYS}

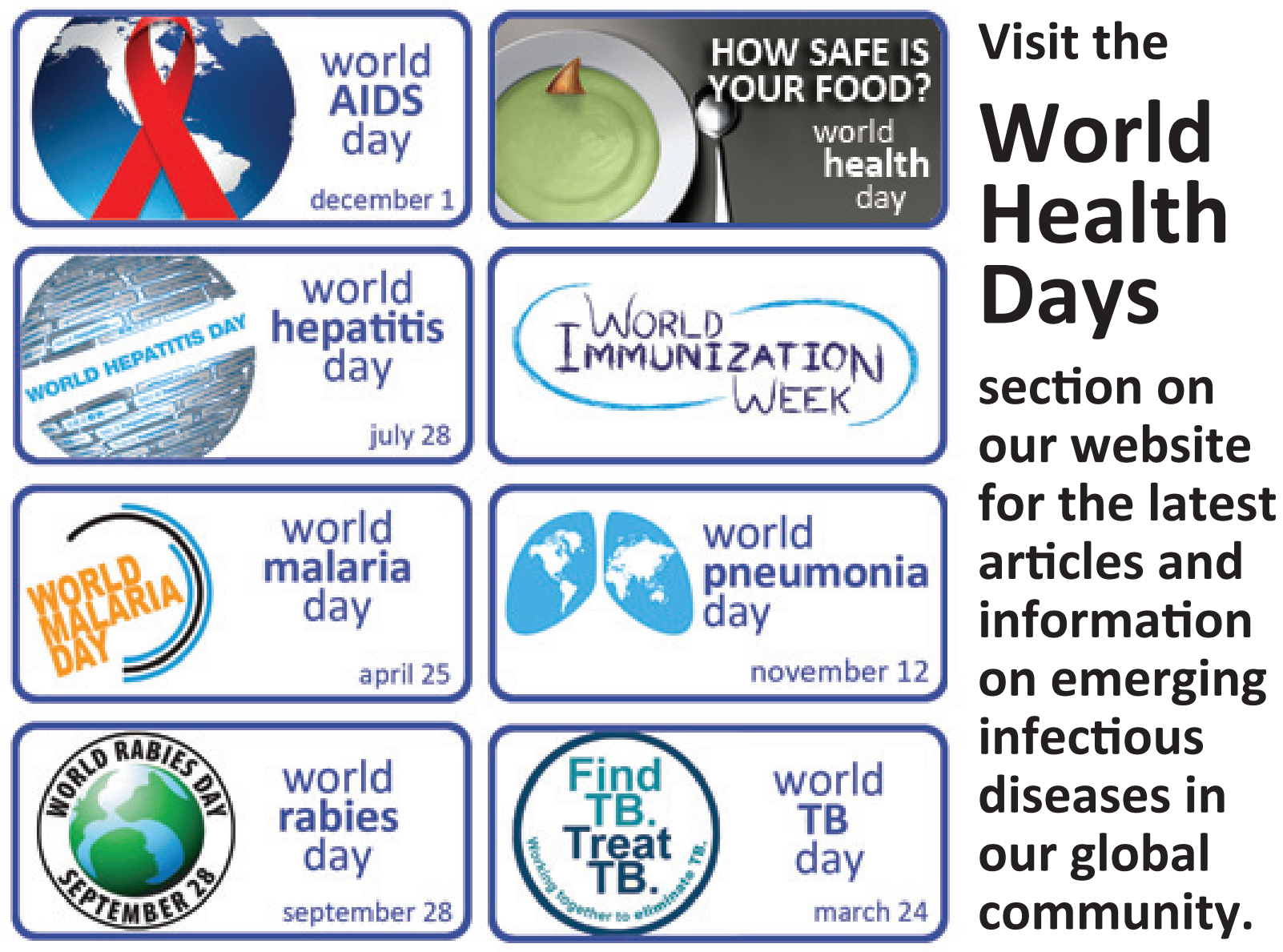

http://wwwnc.cdc.gov/eid/page/world-health-days 